\title{
MENTALITY INFLUENCE ON POLITICAL EVENTS IN UKRAINE
}

\author{
Danylo Stonis \\ Mgr., Charles University in Prague, Czech Republic \\ e-mail: daniell486486@gmail.com,orcid.org/0000-0002-4771-0144
}

\section{Summary}

Since the declaration of independence, Ukraine has been involved in a rapid pace of events, aimed at building statehood and understanding the direction of the political course. However, it is becoming increasingly difficult to understand why, despite a series of revolutions, Russian aggression and numerous difficult steps to democratize the country through decentralization and territorial development, Ukraine has not yet formed a clear political course and ensured the stability of key state institutions, such as judicial, police and taxation systems. Such questions arise quite often and probably do not have an unambiguous answer. This article is devoted to those aspects of the Ukrainian mentality that have caused the current political situation in the state. The article reveals why, despite a series of revolutions, Russian aggression and a number of important steps to democratize countries through decentralization and territorial development, Ukraine does not form a clear political course and does not ensure the stability of key state institutions, such as the judicial, police and tax systems. The article utilizes the method of analysis, which is based on the comparison of historical events and their reflection in modern conditions. In addition to the aforementioned, the method of induction is introduced, which provides possibility of identifying a pattern in the presence of a limited amount of observations of recurring historical events. The article contains sections that consistently consider the historical facts, that have influenced the formation of the mentality of Ukraine, which has a significant impact on the formation of society and the choice of the leader, elected by the society. The article seeks to reveal the causes of certain political events in Ukraine from the influence of the Ukrainian mentality on them and to consider those aspects of it that hinder or help Ukrainians in the difficult process of state building. The purpose of the article is to determine the factors shaping the Ukrainian mentality that have an impact on the political processes that have been taking place for decades in Ukraine. The article does not criticize or accept the Ukrainian mentality, but on the contrary, reveals its historical stages of formation and influence on political processes in Ukraine in order to analyze, understand and predict them.

Keywords: Ukraine, Mentality, Society, Liberty, Freedom, Self-governance, Election.

$$
\text { DOI https://doi.org/10.23856/4327 }
$$

\section{Introduction}

In recent years, a lot of attention in Ukraine has been paid to the process of statehood building and determining the direction of the political course. However, it is becoming increasingly difficult to understand why, despite a series of revolutions, Russian aggression and numerous difficult steps to introduce democratic reforms to the country through decentralization and development of local communities, Ukraine has not yet formed a clearly defined political course and ensured the stability of key state institutions, such as judicial, police and taxation systems. Ukrainian society demands order and justice, but at the same time, it does not want 
to strictly abide by the law. As a result of such social behavior, everyone knows the law, but for some reason is not very respected, and this is done purposefully and easily. Furthermore, such behavioral paradigm has been imprinted in the mindset and worldview of the Ukrainian society throughout history, for example, Ivan Sirko, the famous leader of Ukrainian Cossacks, said, "The need changes the law" (Yavornytsky, 1990). This statement quite possibly reflects the national mentality of Ukraine, which was shaped over the centuries and expressed demand for freedom and independence.

It is widely acknowledged, that mentality of the nation has a significant impact on the formation of society as well as personal qualities and choices of leader who will lead the society. It is the worldview and values of society that determine its further direction of development and stereotypes of behavior. Such behavior affects the attitude of society towards power, towards moral and ethical concepts. The way society perceives the general concept of power has been formed over the years and even today it can be seen how the mentality of society affects the results of local elections, which were characterized by the election of predominantly newly formed local parties as opposed to all-Ukrainian parties. This phenomenon reflects the fundamental aspects of the national mentality that guides Ukrainian society in election of a leader. The choice of a leader at the central or regional level largely depends on what way of life members of society lead and what qualities they endow the future leader with. The 2020 local elections, which demonstrated public distrust of the central leadership, have led to ubiquitous support for local leaders at the regional level. Why does this tendency prevail in Ukraine and how can the mentality be reflected in our choice and understanding of law and justice, trust or distrust of government?

These questions can be asked indefinitely and each time a different answer will be received. This article attempts to solve the conundrum of the Ukrainian mentality. In order to do this, it is necessary to consider the events of today, as well as history and facts.

\section{Understanding the phenomenon of Ukrainian mentality}

Since the declaration of independence on August 24, 1991, Ukraine has been involved in a constant cycle of reforms and transformations, characterized by a complete loss of public confidence in almost all of government institutions without exception. Of course, in such circumstances, any actions of the authorities find neither understanding nor support among the population. Constant dissatisfaction with the government leads to the fact, that the state is unable to perform the most basic functions: it does not protect the lives and property of its citizens, does not provide a credible level of education and healthcare, dooming most of its citizens to permanent existence in bureaucratic chaos and uncertainty in the future, complemented by fear and irritation in society. As a result, the chronic problem of Ukraine is presented by the weakness of state institutions, the constant change of leaders without determining the firm course of actions and political vector of development of the state, the constant distrust of the population to the government, which results in dissatisfaction with its actions. Most Ukrainians barely rely on social protection from the state, trying to solve social problems on their own, such as obtaining benefits, insurance and pensions. This is evidenced by the large number of practices in enterprises, when salaries are partially given in envelopes, not to mention the large number of transactions carried out between individuals for construction, repair and other services. Therefore, the vast majority of financial transactions is not recorded or taxed anywhere at all, and accordingly, no social charges are made against them. And interestingly, this situation suits not only employers but also workers. That is, people do not expect any kind of social 
protection from the state. Instead, population mostly relies on its own savings and investments, which will eventually bring a stable income in the future.

As far as I am concerned, the main reason for dissatisfaction with the government and constant changes in the leadership of the state and state institutions is represented by the national mentality of Ukrainian society, which results in a weak concept of national identity in the conscience of most Ukrainians, giving it a secondary role. Nowadays, the problem of the Ukrainian mentality is exacerbated as never before, as Ukraine has failed to establish a firm, clearly defined political course of actions for almost 30 years of independence and has not provided a well-established system of state institutions that is capable of responding to citizens' requests in a timely and proper manner. In order to build a state, Ukrainian society needs to understand itself, to determine the peculiarities of the population's worldview of the state. Only the identification and implementation of those components of the Ukrainian mentality, that embody national values, is able to revive the national identity, the historical individuality of the people who unite around the national idea. For the further development of Ukraine on a democratic basis, one of the key driving forces is the Ukrainian mentality as a factor in the formation of national identity and national idea.

In my opinion, in order to understand the modern image of Ukrainians as a community, it is important to understand the phenomenon of the Ukrainian mentality. The mentality can be viewed from different angles. Traditionally, mentality is defined as a characteristics of the specifics of perception and interpretation of the world in the system of spiritual life of people, nation and social subjects, embodied in certain socio-cultural phenomena. The content of mentality is determined by the established, embossed by historical experience forms and ways of expressing intellectual and emotional reactions by stereotypes of behavior, archetypes of culture, and socio-psychological attitudes of social subjects (Krymsky, S. \& Zablotsky, V.: 369). Mentality is a deep level of collective and individual psychology, including the subconscious, as well as a set of readiness, attitudes and beliefs of an individual or social group to act, think, feel and perceive the world in a certain way, depending on traditions, customs, social institutions and the social environment (Danyliuk, 2010).

One of the main features of mentality - in contrast to doctrines and ideological constructions, which are complete and meaningful systems, is its openness, incompleteness. Mentalities express not so much the individual guidelines of each of the people, as the impersonal side of public consciousness. The subject of mentalities is not the individual, but society, community. They are manifested in verbal language (verbal culture of society) and sign language, behavior, customs and beliefs (Halushko, 2009: 615).

\section{Specifics of the Ukrainian mentality}

In my opinion, there are two main stereotypes of the Ukrainian mentality that cause the current political background in the state:

The first one, is characterized by the constant change of leaders without defining a firm course of actions, policy, directed towards state building.

The constant change of leaders is caused by the fact that Ukrainians are very self-sufficient in terms of organization. Ukrainians are very enterprising, active and generally entrepreneurial people who follow the leader only when he promises them personal benefits, which are expressed in financial well-being. Most Ukrainians are not interested in such common values for the nation as the prestige of the country, quality of life, clean environment, stable development. Not only every Ukrainian tries to create their own, personal living conditions exclusively 
for themselves, without compromising with other members of the society, but on the contrary, treats them as competitors or not as smart and agile as themselves. As a result, Ukrainians elect a leader, who promises financial benefits in the future, but will not set mandatory rules and regulations for all. This leads to a situation, where everyone sets their own rules and considers them as the best. However, when a leader is going to establish some general rules for everyone, Ukrainian society unites against such a leader, attempting to replace them with one, who will not interfere in the established social order and will not try to change it. Therefore, there is no clear course of actions in the policy of the state, because almost every member of Ukrainian society chooses their own direction and is guided by their own views. Such a worldview is a definition of freedom for Ukrainians, which they do not want to give up to anyone else, even for the benefit of all Ukrainian society, the whole nation.

In spite of the aforementioned, it can be concluded, that Ukrainians want not so much liberty as freedom. The prevalence of freedom as the dominating concept of national idea, is demonstrated in the original motto of the fighters for the independence of Ukraine, both among the Haidamaks and in the Kholodny Yar Republic, which is "The freedom of Ukraine or Death" (Volia Ukrainy abo smert). In my opinion, this motto acts as an embodiment of the mentality of the Ukrainian nation, because Ukrainian term "liberty" (svoboda) is an institutional phenomenon, while the corresponding national origin (volia) "freedom" means first of all liberation, independence from something or somebody (Popovych et al, 2006). If we take into account that "liberty" means a socio-legal institution that determines first of all the rights, social norms and responsibilities in society, then "freedom" acts as the equivalent of personal happiness, as a purely personal independence. Freedom in the Ukrainian mentality is perceived as the highest and most valuable good, which can be obtained only by one's own blood, by one's own efforts. Thus, in Ukrainian society, freedom means, first of all, individual independence from any government, which is perceived as a negative external factor imposed against the will of each individual member of society, and therefore against the people of Ukraine, and negative influence of which must be constantly counteracted or completely eliminated. But this does not mean that Ukraine is characterized by complete anarchy and absence of a leader. Throughout Ukrainian history, since the days of Kyivan Rus, Ukrainians have consistently demonstrated in social behavior a lack of instinct for submission, namely, disciplinary duty, non-recognition of the authority of others and authority per se. These features of the national character were tragically manifested in the period of feudal fragmentation in Kyivan Rus, the Cossack meeting, called chorna rada, which led to a period of Ukrainian history, called "The Ruin" and the atamanship, represented by numerous partisan squads, who acted during the Ukrainian Revolution in 1917-1921. However, ideas have always been authoritative for Ukrainians: respect and recognition of authority has developed in the form of glorification and protection of the idea (defense of Orthodoxy, Cossack rights, the idea of independence) (Abramova, 2008).

The leader in Ukraine has never been perceived as an absolute and adamant force to be obeyed for the common good or for fear of imminent punishment and expulsion from the community. The leader acted as a person chosen by the free community to implement its plans and goals. As long as the leader acts according to the will of the community, they enjoy authority and respect. At the same time, the leader is not perceived by the community as a representative of the nobility or the upper social class. The community treats them as an equal, and may therefore overthrow them and elect another leader if people notice, that the leader is trying to establish certain rules and responsibilities and forces the community to abide by them by coercion or by invoking the supreme, sacred nature of power. which society must unquestionably obey. 
Based on the aforementioned, it can be argued, that this type of social mentality was formed and fixed in the minds of Ukrainians due to the long-term absence of a stable stratum of the Ukrainian intelligentsia, thinkers who would develop the national idea and determine the national traits, around which society could unite and create its own nation. Hence, the Ukrainian society was ruled by foreign countries with different values and worldviews.

Therefore, Ukrainians perceived power as the root cause of misery and captivity, which forced him to rely on his own. Nobody has the right to teach a Ukrainian how to have better and more appropriate lifestyle, because every person is a self-sufficient master of its life and creates its own fate. Ukrainians were forced to rely on their own strength and independent search for their destiny, their way of life, which caused competition and conflict within society, because everybody was convinced that their worldview and way of life is more profitable, successful and better than other members of society. According to the prominent Ukrainian educator and researcher of the Ukrainian mentality Hryhorii Vashchenko:

"The ambition and individualism inherent in Ukrainians, in politics leads to the fact that the struggle for power becomes acute, conflictual, and sometimes tragic. For the average Ukrainian, power is violence that can only be subjugated through fear, not voluntarily. When it weakens, anarchy often occurs, because after the death of the "father" (the authorities) "the sons of Ukraine" try not to allow each other to the vacated place" (Vashchenko, 1992: 33).

Such ambition and self-sufficiency of the nation contributed to the absence of the need to create a hierarchy in society led by a leader, who would be recognized by society and followed by it. In Ukraine, each household had ample means of safe living and therefore elected a leader, who promised easy and affordable benefits to society. The state was not perceived as a necessity for the development and prosperity of the community, because the citizen could achieve a decent standard of living on their own, without the help of community members or government intervention. The need to unite around the leader was needed only when the leader promised to gain quick, temporary benefits for everyone in the short term. Ukrainians willingly elected such a leader, because they saw the need not in a strong leader who will build and develop a powerful and stable state system in society, which, in turn, will ensure the sovereignty of territories and the recognition of state in the international arena, but as a temporary ruler, who has gathered around themselves a group of people who share their purpose and interests, and who, after achieving their common goal, must disband the group without claiming to further leadership on any basis. In the Ukrainian mentality, each member of society represents their own law and order, and at their own risk and discretion build their small state around themselves in accordance with their understandings and capabilities. The need for a leader arises when a common benefit or threat emerges, that can temporarily evoke the interest of individuals in a leader. Power for Ukrainians appears in the form of a negative external factor, which is not something superficial, sacred and inviolable.

As a result, a clearly defined concept of the national idea is not formed in society, which in turn does not allow Ukraine to build a clear strategy for the development of the state and position itself as a reliable and stable partner on the world stage. Foreign countries are reluctant to cooperate with Ukraine because of its unpredictability and inconsistency. The course of actions requires a certain idea, a goal, that society implements by creating a system of social, political, economic, cultural and other institutions, capable of forming the state, which gradually and systematically implements the goal, set not so much by a group of disparate people living in common territory, but by a nation, that creates such living conditions, which are beneficial to all members of society, to all citizens. In Ukraine, every citizen still shapes their way of life and their worldview as they see fit. Therefore, Ukrainian society is unstable, it is constantly 
in a state of competition and conflict between citizens, which does not allow to establish stable and long-term relations with other states, and what can benefit external and internal enemies.

The second stereotype of the Ukrainian mentality can be characterized by the prevalence of personal instant benefit over the gradual and consistent program development of territories.

A distinct feature of the Ukrainian mentality is individualism, namely its focus on separating the individual from the rest of society by uncompromisingly following their own beliefs and views, directing all efforts of the individual to create their own unique world, to isolate it and protect themselves from community and society as a whole. Thus, it is possible to explain the phenomenon of the Ukrainian mentality, when the society of individualists catastrophically lacks creative personalities, people with leadership qualities. At the same time, other characteristics of egocentrism of Ukrainian society are noted. With an excessive focus on their own identity, followed by social indifference, Ukrainians have the ability to quickly self-organize against a person or group of people, who try to impose any norms and rules on the rest of society by forming government institutions and coercive mechanisms. Such self-organization in Ukrainian society is called a revolt against injustice and oppression, which is exacerbated by possible shift towards anarchism.

As a result, Ukrainians do not recognize any authority over themselves. Everybody believes that they can become a leader and they do not feel helpless without a leader, thus, they do not need to depend on him. Such thinking results in a constant change of leaders without determining a firm course of actions as well as the political direction of the state.

Ukrainian society comes to the recognition of authority under the influence of mood, momentary delight, rather than as a result of a balanced and logical analysis of its virtues and deeds. Ukrainians are mostly in opposition to any government (today they cast their votes, and in a few months they blame their own elected officials for all the troubles); the disappointment in government urges people to establish social justice by voting for a new source of power, a new leader, which promises to provide such justice. Such self-centrism, combined with other aspects of the Ukrainian psyche - sensory and emotional, leads to the fact, that Ukrainian society becomes very susceptible to arguments, which appeal to traditional family and national values, arguments that appeal to a sense of individuality, the importance of their own experience. As for the political sphere, Ukrainian society does not accept rapid and radical political changes, which is one of the reasons why democratic reforms in Ukraine are much slower than in other post-communist countries. The political and managerial establishment (representatives of which come from rural or small provincial towns), which tends to apply already approved and tested means to solve political problems, is skeptical of new ideas (Vonsovych, 2008).

Overall, Ukrainians do not see state power and the hierarchy created by it as a guarantee of their own development, prosperity and security. Every Ukrainian has his own strength to create and ensure their own development, well-being and security. Therefore, the Ukrainian perceives power as something temporary, something that does not concern them personally and will not affect their well-being.

\section{Contemporary political consequences of the Ukrainian mentality}

An interesting example of the manifestation of the Ukrainian mentality was the result of decentralization and development of local communities, initiated by Ukrainian government. It should be acknowledged, that the development of local self-governed administrative units is positively perceived by Ukrainian society and it actively participates in the development of local self-governed institutions and in activities, aimed at self-governance of local communities. 
However, recent local election in Ukraine has demonstrated a tendency, when regional communities elect local political parties, in order to gain political influence in the region, thus undermining the true vocation of communities, which is to ensure self-governance and sustainable community development. Despite the fact, that the local election, according to experts, was competitive and generally complied with the legislation, it has also provided an opportunity to elect political party, rather than political candidate (Liskovych, 2020).

Thus, the local election on the one hand demonstrates the positive effect of decentralization, which in almost all regions of Ukraine was won by the mayors in office and the political parties they represent, but on the other hand, it has led to an emergence of the significant number of extra-parliamentary parties in several regions, such as Vinnytsia, Ivano-Frankivsk, Khmelnytsky, Chernihiv (Central Election Commission, 2020). The local population usually chooses its compatriots, regardless of their political views and moral background, believing that such a leader can be manipulated, in order to obtain certain benefits and concessions. Such regional policy is encouraged not only by the lack of reliable and democratic legislation, but also by the reluctance of both candidates for local mayors and the electorate to abide by laws and regulations.

Moreover, it becomes obvious, that the population considers such a situation in the country beneficial for themselves, because it does not matter, which kind of leader will be in charge, as long as it is possible to bargain with them for certain financial or social concessions and benefits. The consequence of this attitude towards the authorities is that regional entrepreneurs seek to become the head of the local community at any cost, only to solve their own problems and promote their own business, not to help community development and ensure stable prosperity in the region. Local communities, in turn, are happy to accept petty encouragement and populist promises from candidates, as they do not realize that having liberties, unlike freedom, requires, first of all, responsibility for leader's actions in office, responsibility to the community, strict supervision and implementation of the party program. Instead, the local population seeks to use its ties to local entrepreneurs, so that the law does not limit their activities in any way or hold them accountable to the law or the community for their business or other activities.

Now we see how the media are actively promoting great patriots, deputies, public figures, who, if you dig deeper, have three parties behind them in the past, which they changed a long time ago. They speak and change their slogans, depending on the needs of Ukrainians, on what is profitable. And unfortunately, we have a lot of people who believe what they are told. Why can't Ukrainians unite? Sometimes there are things when we do not want to give up something. Because everyone wants to be on top, they compete in patriotism. In our country, most parties act as they see fit (Malko, 2020).

\section{Conclusion}

The situation in the society as a result of the 2020 local election in Ukraine can be considered as a noticeable tendency to strengthen local authorities. In the majority of regions, local candidates came to power, nominated by newly formed parties, where instead of a clear course of actions, designed for the gradual and long-term development of the community, they offer quick and effectively solution for the economic crisis in the region. The result of local election suggests, that populist political projects are gaining more influence in the regions of Ukraine, whilst democratic parties face social distrust, caused by the disappointment of the majority of the population with the policies, pursued by the central government. The population of the country is more interested in their own well-being than in creating a common good for the region, the state. 
Hence the tendency for communities in Ukraine to perceive fairness not as the application of written law, but rather as a natural exigency of community. Ideally, spravedlyvist (justice) is achieved through a pravova spilnota (righteous community) that does not require a state, as the latter can be hijacked, whereas the community's "natural law" reflects the common good (Wynnyckyj, 2020: 132).

Therefore, the results of the local election clearly show that a large part of the Ukrainian community is convinced, that the creation of a just social order is possible at the local level in accordance with generally accepted norms, which are followed by the majority of the population in the region. The central government is perceived as an entity, that outlines general trends and provides general recommendations that serve more as guidelines, rather than rules.

Naturally, these factors significantly prevent Ukraine from overcoming the difficult economic and socio-political situation and successfully implementing anti-corruption measures in various spheres of Ukrainian society. At the same time, the stable self-governing potential of the Ukrainian mentality, the traditional natural democracy of the Ukrainian people, their psychological rejection of the authoritarian nature of the central government creates favorable opportunities for its self-realization, which can serve in socio-political and state-building practice. Ukrainians must become conscious citizens of their country, who think not only about their own well-being, but also about the common good for the whole community.

\section{References}

Abramova, I. G. (2008). Do problemy ukrainskoii mentalnosti [To the problem of Ukrainian mentality]. Visnyk Zaporizkoho natsionalnoho universytetu - Bulletin of the Zaporizhzhia National University, 2, 7-11. Retrieved from https://web.znu.edu.ua/herald/issues/2008/ fil_2008_1_2/2008-26-06/abramova.pdf [in Ukrainian].

Danyliuk, Ivan. (2010). Etnichna Psykhologiia yak haluz naukovoho znannia: istoryko-teoretychny vymir [Ethnic psychology as a branch of scientific knowledge: historical and theoretical dimension]. Kyiv: Sammit-knyha [in Ukrainian].

Halushko, K.Y. (2009). Mentalnist, Mentalitet [Mentality, Mindset]. Entsyklopediia istorii Ukrainy - Encyclopedia of the History of Ukraine, (Vol. 6), [in Ukrainian].

Krymsky, S., Zablotsky, V. (2002). Mentalnist [Mentality]. V. I. Shynkaruk (Eds.), Filosofsky entsyklopedychny slovnyk - Philosophic encyclopedic dictionary: The National Academy of Sciences of Ukraine Hryhorii Skovoroda Institute of Philosophy. Kyiv: Abrys, 2002.

Liskovych, M. (2020). Mistsevi vybory-2020: pidsumky, tendentsii ta shcho bude dali [Local elections 2020: results, trends and what will happen next]. Ukrinform. Retrieved from https:// www.ukrinform.ua/rubric-elections/3142240-miscevi-vibori2020-pidsumki-tendencii-ta-sobude-dali.html [in Ukrainian].

Malko, R. (2020). Oksana Savchuk: “Krainou keruyut liudy, yaki duzhe zalezhni vid dumky oliharkhiv [The state is governed by people, who heavily depend on oligarchs' opinion]. Ukrainsky Tyzhden - The Ukrainian Week. Retrieved from https://tyzhden.ua/Politics/248863 [in Ukrainian].

Mistsevi vybory Ukrayina 2020. Tsentralna vyborcha komisiya [Local elections Ukraine 2020. Central electoral commission]. Retrieved from https://www.cvk.gov.ua/pls/vm2020/pvm002pt$001 f 01=695$ pt00_t001f01 =695.html [in Ukrainian].

Popovych, M. V., Kysliakovska, I. V., Viatkina, N. B., Navrotsky, V. V., Vasylchenko, A.A., Kokhan, Y. O., et al. (2006). Problemy teorii mentalnosti [Problems of mentality theory]. 
Kyiv: Naukova Dumka. Retrieved from http://www.filosof.com.ua/Mentaltheorie/P11.pdf [in Ukrainian].

Vashchenko, H. H. (1992). Psykhichni vlastyvosti ukraintsiv i prychyna nashykh nevdach [Mental properties of Ukrainians and the reason of our failures]. Ridna shkola - Dear School, 2, 31-35 [in Ukrainian].

Vonsovych, H. B. (2008). Rysy mentalnosti ukrainstva yak skladova politychnoi svidomosti [Features of the Ukrainian mentality as a component of political consciousness]. Problemy suchasnoi psykhologii - Problems of the modern Psychology, 2, 63-74. Retrieved from http:// journals.uran.ua/index.php/2227-6246/article/view/163230/162200 [in Ukrainian].

Wynnyckyj M. (2020). Unravelling the Ukrainian Revolution: “Dignity," "Fairness," “Heterarchy," and the Challenge to Modernity. Kyiv-Mohyla Humanities Journal, 7, 123-140. Retrieved from http://kmhj.ukma.edu.ua/index.php/2313-4895/index.

Yavornytsky D. I. (1990). Istoriya Zaporozhskikh Kazakov [The History of the Zaporizhzhia Cossacks]. Kyiv: Naukova Dumka, 1990. Retrieved from http://www.cossackdom.com/book/ bookyvor/izk2/214.html [in Russian]. 